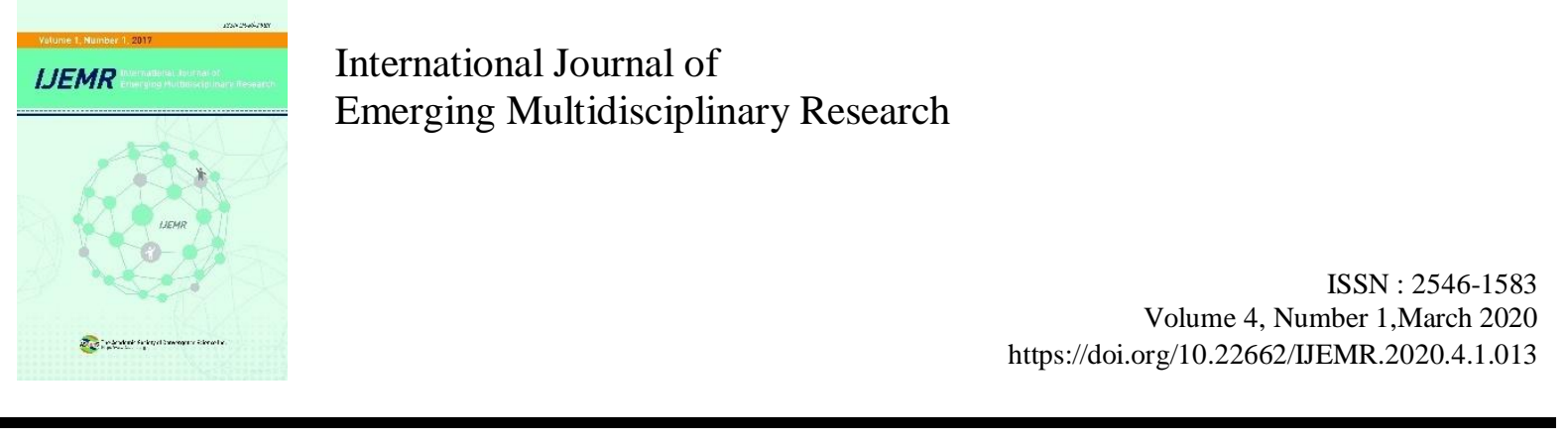

\title{
A research on students' readiness for Education 4.0 program
}

\author{
Le Hoanh $\mathrm{Su}^{1}$, Nguyen Thi Hong Linh'², Vo Dang Hong Ngan², Le Kieu Oanh², Nguyen \\ Ngoc Thanh', Tran Vuong Bao Tran ${ }^{2}$ \\ ${ }^{1}$ Faculty of Information Systems, University of Economics and Laws, VNU-HCM, HCMC, Viet Nam \\ ${ }^{2}$ Faculty of Business Administration, University of Economics and Laws, VNU-HCM, HCMC, Viet Nam
}

\begin{abstract}
Background/Objectives: The purpose of the study is to find out the factors affecting student readiness for education 4.0. Methods/Statistical analysis: Based on 361 samples, this quantitative research was conducted: reliability testing, exploratory factor analysis, correlation coefficients and linear regression. The result shows that there are four key factors affecting readiness including Self-regulation, Creativity, Upgrade and Attitude. Findings: The result of t-test shows that the group of students who had experienced online learning had higher readiness for the education 4.0 than the others. Improvements/Applications: The advantages that students realize when being involved in the 4.0 education system will help them greatly improve their skills and knowledge.
\end{abstract}

\section{Index Terms}

Education 4.0, Readiness, Internet self-efficacy, Online communication self-efficacy, Self-regulation, Creativity, Selfdiscovery, Upgrade, Collaboration, Attitude.

\footnotetext{
Corresponding author : Le Hoanh Su

sulh@uel.edu.vn

-Manuscript received February 1, 2020.

-Revised February 29, 2020; Accepted March 5, 2020.

-Date of publication March 31, 2020.

(C) The Academic Society of Convergence Science Inc.

2546-1583 @ 2017 IJEMR. Personal use is permitted, but republication/redistribution requires IJEMR permission.
} 


\section{INTRODUCTION}

According to the World Economic Forum (WEF), by 2020 , many jobs in the global labor market will disappear, people will lose 5 million jobs due to being replaced by robots.

The Industrial Revolution 4.0 could create the risk of breaking the labor market around the world including Vietnam with automation machines that can replace humans. Therefore, to keep up with the impact of the Industrial Revolution 4.0, Education 4.0 is assessed as an appropriate education model. Rajan Saxena [1] et al. (2017) said that education has undergone four stages, namely:

Education 1.0: From ancient period to the Middle Ages, education was imparted on a person-to-person basis, so it was limited in scale and informal in nature;

Education 2.0: The invention of the printing press allowed people to get access to basic education, thus created a culture of scientific inquiry;

Education 3.0: The emergence of internet and IT changed the mode of delivery, providing a technology platform to learn;

Education 4.0 puts the learner at the center of the ecosystem and empowers him or her to structure individual paths keeping in mind the final outcome.

In fact, many educational institutions in Vietnam have actively approached the new wave of educational technology, to deploy training based on MOOC courses, bring AI and VR into designing the study system or deploy intelligent digital learning systems.

Hanoi National University is developing at the university level of 2.0 - UniWood, but there are also many premises for the 4.0 model. That is to prioritize research and development of basic technologies of industry 4.0 such as gene technology, Internet of things technology (IoT), nanotechnology, materials, energy and especially 3D printing technology but always ensure the balance of the economic socialenvironmental triangle of sustainable development.

To research about the readiness of student, some of definitions of readiness have been explored as follows: Readiness is formed by the changing in nature of work that forces persons to adapt with new situations (Katherin Prince at el., 2017) [2].

Readiness is defined as a measure of how a new problem is proposed and applied (Semih Caliskan et al., 2017) [3]. More specifically, readiness in applying technology 4.0 is the organizational capacity and the ability to adapt other involved educational solution (management, key personnel, professors and students) to an electronic model.

There are many factors affecting the readiness in applying technology 4.0 such as e-commerce, electronic payment, e-learning. According to Akaslan and Law (2011) [4], readiness, especially in learning, is the ability of an organization or individual to take advantage of learning. The research about student readiness is necessary in order to study the current phenomenon.

Theoretically, the study aims to find out the factors affecting student readiness for the Education 4.0. In terms of practical implications, the research results will provide useful information for universities so that they can identify students attitude toward the importance of Education 4.0 and help universities design their own educational models in accordance with standards of Education 4.0 and make a premise for research in the future.

\section{LITERATURE REVIEW}

\section{A. Previous Studies}

Katherine Prince et al (2016) [2] predicted the main characteristics of work in the future readiness as the rise of smart machines, the decline of full-time employees, accelerating technology and proposed a framework to redefine with four scenarios in the future of readiness: partnering for mobility, checking for upgrades, finding new meaning, working with platforms.

There are two important uncertainties that could affect readiness by 2040: "will there be high or low technological displacement of human workers?" and "will the societal response be systemic and international or market driven?". Besides, Alan S. Waterman (2011) [5] mentioned how to measure happiness in suitable way and conception of philosophy of happiness.

The goal of identity formation is identified as discovering the nature of one's daimon which includes the discovery of personal potentials, choosing one's purposes in living, and finding opportunities to perform those potentials and purposes in living. The contributions of these subjective experiences and predictors to the goals and processes of identity formation will be explored. In addition, "Learner readiness for online learning: Scale development and student perceptions" (M.-L. Hung et al, 2010) [6] is a study whose purpose of this study was to develop and validate a multidimensional instrument for college students' readiness for online learning.

Readiness Scale (OLRS) was validated in five dimensions: self-directed learning, motivation for learning, computer/internet self-efficacy, learner control, and online communication self-efficacy

\section{B. Self-efficacy}

Bandura (1997) defined self-efficacy as a level of how an individual ability of his or her behavior in order to achieve the desired goals. Self-efficacy involved how much effort an individual put into solving problems in a tough situation, to reinforce spirit against adversity and seek immediate solutions. (Ipek \& Acuner, 2011) [7]. 
During learning process, self- efficacy seems to be an important factor that can impact on student behaviors (Pajares, 2006; Schunk, 2003) [8,9]. Some researchers also examined the influence of student self-efficacy on motivation and learning (Schunk, 2003) [9].

Besides, Compeau and Higgins (1995) [10] said that internet self-efficacy of students has an effect on results of the ways they used internet in daily life. In this study, self-efficacy is measured in two aspects: internet and online communication. Therefore, we suggest two hypotheses:

H1: Internet self-efficacy positively affects students readiness for education 4.0.

H2: Online communication self-efficacy positively affects student readiness for education 4.0.

\section{Self-regulation}

Schunk et al (2003) [9] defined self-regulation as a process in which students activate and maintain systematically awareness, influence, and orientation to achieve their goals. In addition, Shyu et al (1992) [11] have indicated that self-regulation is a level of how students can orient their own experience and learning process.

According to research, Artino et al (2008) [12] and Peachter et al (2010) [13] have showed that there is a positive relationship between using self-regulation strategies and student performance and satisfaction with online courses. The research also indicated a statistical relationship between self-regulation learning outcomes and the course outcomes. Thus, the next hypothesis is H3: Self-regulation positively affects student readiness for education 4.0.

\section{Creativity}

Creativity is the ability to create new knowledge (Dacey \& Lennon, 2000) [14]. Creativity is also about applying knowledge and skills in new ways to achieve a valuable goal (Vernon, 1989) [15]. Students who are flexible in solving problems creatively have showed a high level of performances in Doss's study (2018) [16]. Besides, Jules and Sundberg (2018) [17] recommended that employees could extend their time working for a company by applying creativity and innovation in the workplace.

Fleenor (2018) [18] has also indicated that creative courses would show a reliable forecast for student confidence and capability to prepare for various environments. The following hypothesis is proposed H4: Creativity positively affects student readiness for education 4.0 .

\section{E. Self-discovery}

E. Katherine Price et al (2016) [2] has pointed out that self-discovery is the deep understanding of oneself to pursuit their own passion, to find a work that is meaningful for them and useful for the community. Self-discovery is also the formation of thorough awareness of one's personalities by searching for intrinsic nature and value to identify goals, values and beliefs (Waterman, 2011) [5]. Schwartz et al (2000) [19] has previously showed the relationship between self-discovery and identified achievements. Self-discovery gives us a great chance for understanding ourselves and becoming successful (Vansteenkiste et al 2009) [20].

Thus, it is hypothesized that H5: Self-discovery positively affects student readiness for the education 4.0.

\section{F. Upgrade}

Upgrade was defined as the activity of using programs that allow users to enhance their professional skills in the workplace. Katherin et al (2017) [2] also supposed that upgrade is the improvement of a professional worker's performance from one project to another through improving his/her skills, digital tools and social knowledge. Consequently, Katherine Prince et al (2017) [2] has mentioned upgrade as an essential factor for helping us adapt to new environments and jobs as well as distinguish qualified employees from others.

The next hypothesis is H6: Upgrade positively affects student readiness for the education 4.0.

\section{G. Collaboration}

Collaboration is described as how people share their specialist knowledge in the process of collective studying (Cronin et al, 2018) [21]. Caniglia (2018) [22] has showed that collaboration promotes research and education in a sustainable way. Collaboration helps education take advantage of differences in culture, language and nationality by presenting challenges and strategies used in international cooperation all around the world. Particularly in education 4.0, collaboration is a tool to help students connect with people and the environment around them to collect necessary knowledge for themselves quickly and easily.

This is the basic of the following hypothesis $H 7$ : Collaboration positively affects student readiness for the education 4.0.

\section{H. Attitude}

Davis (1989) [23] has defined attitude as a function of belief that refers to advantage and disadvantage perception of behaviors. In particular, Woodrow (1991) [24] has found out a positive attitude 
towards technology is necessary to make any educational program successful. Arbuthnott (2009) [25] has also showed another evidence suggesting that attitudes can have a strong impact on behavior, involving planning for an upcoming activity.

The following hypothesis is proposed H8: Attitude positively affects student readiness for the education 4.0

\section{The difference between groups}

There are many studies on difference between factors in a group, such as gender, region, age and experience. Yi-Shun Wang (2009) [26] has pointed out the enormous difference of mobile learning acceptance among ages, genders and education backgrounds. In our study, we propose that different groups of gender, rank (junior and senior students), GPA score have different readiness for education 4.0.

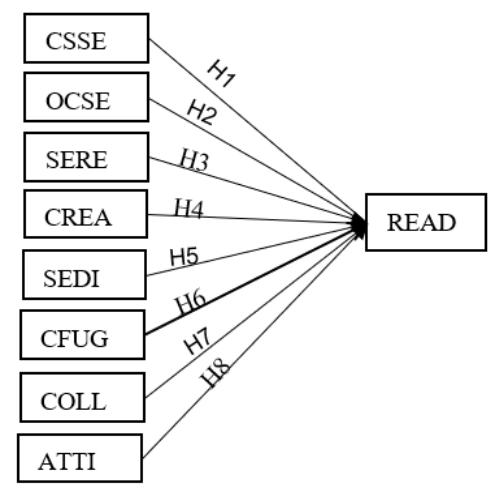

Fig. 1 The proposal model research for the education

\section{RESEARCH METHODOLOGY}

We adopted the questionnaire survey for data collection and examined our hypotheses by applying the linear regression method to validate the model.

The measurement instruments for variables in the questionnaire were developed from previous studies to enhance the variability and reliability. Responses to the various variables related to the perceptions of the individual subjects were measured using Likert-type scale.

The research was conducted with convenience sampling method and then processed with SPSS software. We designed online survey to collect answers from Vietnam National Universities (VNU) students who had known about or studied with education 4.0. Following is the research process.

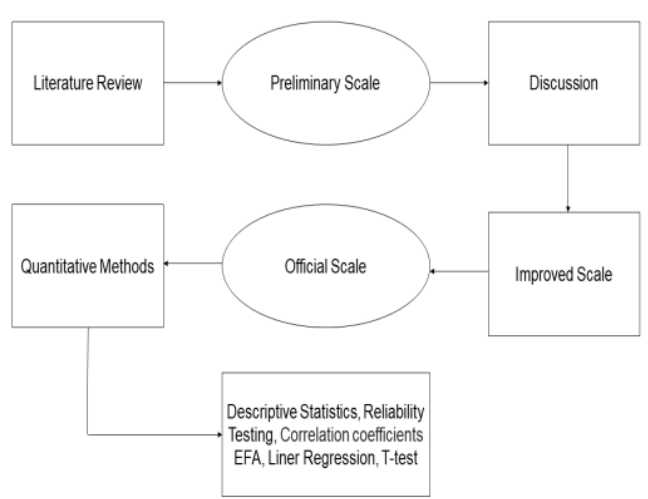

Fig. 2 Research methodology

\section{RESULTS}

\section{A. Sample Information}

The survey completed with 370 valid samples including 214 females $(59,3 \%)$ and 156 males $(40,7 \%)$. Most of the respondents were at third and fourth year $(65,7 \%) ; 159$ students are studying Economics and Administration (44\%). The majority of respondents had a GPA score at least 7.0/10 $(86,7 \%)$. Most of the respondents had experienced studying online $(64,8 \%)$.

\section{B. Reliability analysis}

Regarding Table I, all variables were tested for reliability. All items were acceptable and reliable to measure the constructs: all constructs had a Cronbach's Alpha (CA) of more than 0.60 (from $0,753$ to 0,873$)$.

TABLE 1. REALIABILITY AND CORRELATION MATRIX

\begin{tabular}{|c|c|c|c|c|c|c|c|c|c|}
\hline & $\mathrm{CA}$ & $\begin{array}{c}\text { AT } \\
\text { TI }\end{array}$ & $\begin{array}{c}\mathrm{COL} \\
\mathrm{L}\end{array}$ & $\begin{array}{l}\text { SE } \\
\text { DI }\end{array}$ & $\begin{array}{c}\text { SER } \\
\text { E }\end{array}$ & $\begin{array}{c}\text { OCS } \\
\text { E }\end{array}$ & $\begin{array}{c}\text { CRE } \\
\text { A }\end{array}$ & $\begin{array}{c}\mathrm{CFU} \\
\mathrm{G}\end{array}$ & $\begin{array}{c}\text { REA } \\
\text { D }\end{array}$ \\
\hline $\begin{array}{c}\text { ATT } \\
\text { I }\end{array}$ & $\begin{array}{c}0,87 \\
3\end{array}$ & & $\begin{array}{c}.566 \\
* *\end{array}$ & $\begin{array}{l}.28 \\
9^{*}\end{array}$ & .441 & .370 & .364 & .496 & .704 \\
\hline $\begin{array}{c}\mathrm{COL} \\
\mathrm{L}\end{array}$ & $\begin{array}{c}0,75 \\
4\end{array}$ & $\begin{array}{l}.56 \\
6^{*}\end{array}$ & & $\begin{array}{l}.37 \\
2^{*}\end{array}$ & .457 & .372 & .425 & .554 & .541 \\
\hline $\begin{array}{c}\text { SED } \\
\text { I }\end{array}$ & $\begin{array}{c}0,83 \\
1\end{array}$ & $\begin{array}{l}.28 \\
9^{*}\end{array}$ & .372 & & $\begin{array}{c}.498 \\
* *\end{array}$ & .319 & .423 & .428 & .335 \\
\hline $\begin{array}{c}\text { SER } \\
\text { E }\end{array}$ & $\begin{array}{c}0,75 \\
3\end{array}$ & $\begin{array}{l}.44 \\
1^{*}\end{array}$ & .457 & $\begin{array}{l}.49 \\
8^{*}\end{array}$ & & .294 & .477 & .433 & .492 \\
\hline $\begin{array}{c}\text { OCS } \\
\text { E }\end{array}$ & $\begin{array}{c}0,75 \\
1\end{array}$ & $\begin{array}{l}.37 \\
0^{*}\end{array}$ & .372 & $\begin{array}{l}.31 \\
9^{*}\end{array}$ & .294 & & .360 & .455 & .368 \\
\hline $\begin{array}{c}\text { CRE } \\
\text { A }\end{array}$ & $\begin{array}{c}0,74 \\
6\end{array}$ & $\begin{array}{l}.36 \\
4^{*}\end{array}$ & .425 & $\begin{array}{l}.42 \\
3^{*}\end{array}$ & .477 & .360 & & .449 & .481 \\
\hline $\begin{array}{c}\text { CFU } \\
\text { G }\end{array}$ & $\begin{array}{c}0,79 \\
4\end{array}$ & $\begin{array}{l}.49 \\
6^{*}\end{array}$ & $\begin{array}{c}.554 \\
* *\end{array}$ & $\begin{array}{l}.42 \\
8^{*}\end{array}$ & .433 & $\begin{array}{c}.455 \\
* *\end{array}$ & $\begin{array}{c}.449 \\
* *\end{array}$ & & .544 \\
\hline $\begin{array}{c}\text { REA } \\
\text { D }\end{array}$ & $\begin{array}{c}0,86 \\
6\end{array}$ & $\begin{array}{l}.70 \\
4^{*}\end{array}$ & .541 & $\begin{array}{l}.33 \\
5^{*}\end{array}$ & .492 & .368 & .481 & .544 & \\
\hline
\end{tabular}

\section{EFA Analysis}

After EFA analysis, there are 8 independent measurements: 5 items belong to CSSE, 4 items belong to ATTI, 6 items belong to SEDI, 7 items belong to CFUG, 4 items belong to SERE, 3 items 
belong to CREA, 3 items belong to OCSE and 3 items belong to COLL and 1 dependent measurement: 4 items belong to READ.

\section{Correlation coefficients}

There was a significant relationship between those independent variables and dependent variables (Table $1)$. The Pearson correlation coefficient (r) highest is 0,754 and lowest is 0,541 .

\section{E. Linear Regression}

The relationships between 7 constructs, namely, CSSE, OCSE, SERE, CREA, SEDI, CFUG, COLL and ATTI with 1 construct: READ, were tested by multiple regressions. The results of these relationship, which is shown as model (a) in Table II, revealed that $59,6 \%$ of the variance in Readiness can be explained by variance in the four constructs $\left(\mathrm{R}^{2}=0,596\right.$; $\mathrm{p}<$ 0,001).

\begin{tabular}{|c|c|c|c|}
\multicolumn{2}{|c|}{ TABLE II. LINEAR REGRESSION } \\
\hline & Beta & $\mathrm{t}$ & Sig. \\
\hline (Constant) & & $-0,244$ & 0,808 \\
\hline CSSE & 0,017 & 0,414 & 0,679 \\
\hline ATTI & 0,484 & 10,881 & 0,000 \\
\hline COLL & 0,068 & 1,463 & 0,144 \\
\hline SEDI & $-0,020$ & $-0,488$ & 0,626 \\
\hline SERE & 0,112 & 2,517 & 0,012 \\
\hline OCSE & 0,007 & 0,169 & 0,866 \\
\hline CREA & 0,156 & 3,589 & 0,000 \\
\hline CFUG & 0,147 & 3,186 & 0,002 \\
\hline
\end{tabular}

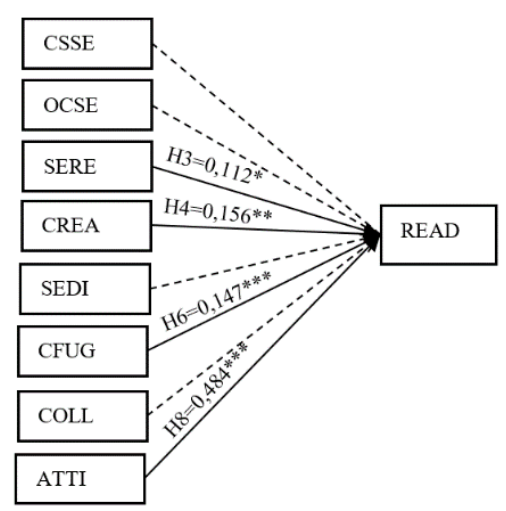

Fig. 1 The Model after analyzing

Attitude was the greatest influence on Readiness $(\beta=0,484 ; \mathrm{t}=10,881 ; \mathrm{p}<0,0005)$. Relationships of the other three constructs, namely Upgrade (CFUG), Self-regulation (SERE) and Creativity (CREA) with Readiness had low coefficients $(\beta=0,198 ; \beta=0,106$; $\beta=0,145)$.
The rest of the postulated constructs| with Readiness Education were rejected in this study, namely Computer searching Self efficacy $(\beta=0,017$; $\mathrm{t}=0,414 ; \mathrm{p}>0,05)$, Online communication Self efficacy $(\beta=0,007 ; \mathrm{t}=0,169 ; \mathrm{p}>0,05)$, Selfdiscovery $(\beta=-0,02 ; \mathrm{t}=-0,488 ; \mathrm{p}>0,05)$ and Collaborations $(\beta=0,068 ; \mathrm{t}=1,463 ; \mathrm{p}>0,05)$.

\section{F. T-test}

The students who had experienced online learning $(\mathrm{M}=3,91 ; \mathrm{SD}=0,65)$ reported significantly higher levels of readiness for education 4.0 than those who had not $(M=3,63 ; S D=.32), t(1)=3,663, p<0,0005$. Those different groups containing gender, GPA score and rank showed insignificant levels of readiness.

\section{CONCLUSION}

This study determined key factors affecting student readiness for the education 4.0 through conducting quantitative research. The results show that 4 factors influent student readiness for education 4.0 while the remaining 4 factors do not. Attitude is the most direct and significant factor affecting the readiness of students of VNU.

Attitude is the level of reaction and expression of an individual when preparing to adapt to new changes or participate in new environment. When they realize that participating in the 4.0 education system is a smart decision, they will pay much attention to it that affects the readiness.

In addition, educational institutions need to create more opportunities for students to practice creative skills, encourage learners to use knowledge in life to create new ideas. Moreover, there should be more academic seminars in order to provide useful information for students about the education 4.0.

Self-efficacy has significant impact on student readiness for education 4.0. Learning on Web is very different from learning in the traditional environment. The instruction on Web provides more flexibility and freedom than in research materials.

Learners are allowed to choose the amount of content, sequences and learning speed with the maximum freedom. In order to improve self- efficacy, learners must set up their long-term learning plan and follow it, know how to manage their time and control their emotions. It is necessary to know how to evaluate results and make quick adjustments.

Creative ability is one of the important factors that influent and play a decisive role in the readiness of students for education 4.0. Learners must have three main qualities: identifying problems in a new way, synthesizing knowledge, creating and developing ideas. Upgrade is one of the important factors that have a direct and significant impact on readiness.

The advantages that students realize when being 
involved in the 4.0 education system will help them greatly improve their skills and knowledge. Therefore, the readiness to participate in this system is also higher. The results of t-test show that there is no difference among groups such as gender, rank and GPA score. However, the readiness of students who have experienced online learning is higher than that of those who have not.

Collecting samples with convenience sampling method is a limitation of this topic because the representation of the sample is not high.

In addition, the next drawback is the sample quality as most students may have known briefly about the education 4.0 but have not deeply understood it. Therefore, the proposal model cannot be utilized well in this current time.

\section{REFERENCES}

[1] Rajan Saxena, H. Vinod Bhat. (2017). Leapfrogging to Education 4.0: Student at the core.

[2] Prince, K., Saveri, A., \& Swanson, J. (2017). The future of learning: Redefining readiness from the inside out. Cincinnati: Knowledge Works.

[3] Caliskan, S., \& Ozcan, D. (2017). Determination of self-efficacy perceptions of special education teacher candidates towards computer course. Ponte, 73(6), 213-223.

[4] Akaslan, D., \& Law, E. L. (2011). Measuring teachers' readiness for e-learning in higher education institutions associated with the subject of electricity in Turkey. IEEE Global Engineering Education Conference (EDUCON), 481-490, IEEE.

[5] Waterman, A. S. (2011). Eudaimonic identity theory: Identity as self-discovery. In Handbook of identity theory and research, 357-379.

[6] Hung, M. L., Chou, C., Chen, C. H., \& Own, Z. Y. (2010). Learner readiness for online learning: Scale development and student perceptions. Computers \& Education, 55(3), 1080-1090.

[7] Ipek, C., \& Acuner, H. Y. (2011). Primary pre-service teachers' computer self-efficacy beliefs and attitudes toward educational technologies. Ahi Evran University Journal of Education, 12(2), 23-40.

[8] Pajares, F. (2006). Self-efficacy during childhood and adolescence. Self-efficacy beliefs of adolescents, 5, 339-367.

[9] Schunk, D. H. (2003). Self-efficacy for reading and writing: Influence of modeling, goal setting, and selfevaluation. Reading \&Writing Quarterly, 19(2), 159172.

[10] Compeau, D. R., \& Higgins, C. A. (1995). Computer self-efficacy: Development of a measure and initial test. MIS quarterly, 189-211.

[11] Shyu, H. Y., \& Brown, S. W. (1992). Learner control versus program control in interactive videodisc instruction: What are the effects in procedural learning. International Journal of Instructional Media, 19(2), 85-95.

[12] Artino, A., \& Ioannou, A. (2008). Promoting academic motivation and self-regulation: Practical guidelines for online instructors. In Society for information technology \& teacher education international conference, 208-212. Association for the Advancement of Computing in Education (AACE).

[13] Paechter, M., Maier, B., \& Macher, D. (2010). Students' expectations of, and experiences in e-learning: Their relation to learning achievements and course satisfaction. Computers \& education, 54(1), 222-229.

[14] Dacey, J. S., Lennon, K., \& Fiore, L. B. (1998). Understanding creativity: The interplay of biological, psychological, and social factors. Jossey-Bass Inc Pub.

[15] Vernon, P. E. (1989). The nature-nurture problem in creativity. In Handbook of creativity, 93-110.

[16] Doss, K. K. (2018). Providing Opportunities for" Flow" Experiences and Creative Problem-Solving through Inquiry-Based Instruction. Global Education Review, 5(1), 108-122.

[17] Jules, T. D., \& Sundberg, K. C. (2018). The internationalization of creativity as a learning competence. Global Education Review, 5(1).

[18] Fleenor, M. C. (2018). Cultivating Experimental Innovation within Undergraduate Physics Majors. Global Education Review, 5(1), 73-87.

[19] Schwartz, S. J., Mullis, R. L., Waterman, A. S., \& Dunham, R. M. (2000). Ego identity status, identity style, and personal expressiveness: An empirical investigation of three convergent constructs. Journal of Adolescent Research, 15(4), 504-521.

[20] Vansteenkiste, M., Sierens, E., Soenens, B., Luyckx, K., \& Lens, W. (2009). Motivational profiles from a self-determination perspective: The quality of motivation matters. Journal of educational psychology, 101(3), 671.

[21] Cronin, C., Cochrane, T., \& Gordon, A. (2016). Nurturing global collaboration and networked learning in higher education. Research in Learning Technology, 24.

[22] Caniglia, G., Luederitz, C., Groß, M., Muhr, M., John, B., Keeler, L. W., \& Lang, D. (2017). Transnational collaboration for sustainability in higher education: Lessons from a systematic review. Journal of cleaner production, 168, 764-779.

[23] Davis, F.D. (1989). "Perceived Usefulness, Perceived Ease of Use, and User Acceptance of Iinformation Ttechnology," MIS Quarterly, 13(3), 319-340.

[24] Woodrow, J. E. (1991). Locus of control and computer attitudes as determinants of the computer literacy of student teachers. Computers \& Education, 16(3), 237 245.

[25] Arbuthnott, K. D. (2009). Education for sustainable development beyond attitude change. International Journal of Sustainability in Higher Education.

[26] Wang, Y. S., Wu, M. C., \& Wang, H. Y. (2009). Investigating the determinants and age and gender differences in the acceptance of mobile learning. British journal of educational technology, 40(1), 92118. 